\title{
Influence of Foliar Application of Mineral Nutrients on Biological Nitrogen Fixation of Rainfed Soybean
}

\author{
Malik Gul Hassan Awan ${ }^{1}$, Shahzada Sohail Ijaz ${ }^{1 *}$, Muhammad Ansar ${ }^{2}$, Adeel Anwar ${ }^{2}$, Umber Abbasi ${ }^{1}$ and \\ Hashmat Mahmood ${ }^{3}$
}

${ }^{1}$ Institute of Soil Science, Arid Agriculture University Rawalpindi, Pakistan; ${ }^{2}$ Department of Agronomy, Arid Agriculture University Rawalpindi, Pakistan; ${ }^{3}$ Soil and Water Testing Laboratory, Rawalpindi, Pakistan.

\begin{abstract}
A field study investigated the effect of foliar nutrients on nitrogen fixation of soybean grown under subtropical rainfed conditions. Three soybean varieties viz. NARC-2, Ajmeri-1 and Rawal-1 were sown with and without foliar application of nutrients $(\mathrm{Mn}, \mathrm{Fe}, \mathrm{Cu}, \mathrm{Zn}, \mathrm{P}$ and $\mathrm{Ca}$ ) in a sandy loam soil (Typic Ustorthents). The spray applied $0.7 \mathrm{~g} \mathrm{ha}^{-1} \mathrm{Mn}, 0.7 \mathrm{~g} \mathrm{ha}^{-1} \mathrm{~B}, 0.7 \mathrm{~g} \mathrm{ha}^{-1} \mathrm{Cu}$, and $1 \mathrm{~g} \mathrm{ha}^{-1} \mathrm{Zn}$ besides $59 \mathrm{~g} \mathrm{ha}^{-1} \mathrm{P}$, and $27 \mathrm{~g} \mathrm{ha}^{-1} \mathrm{Ca}$. Foliar application enhanced the nitrogen fixation in all the soybean varieties. Increase was 98\% in NARC-2, 84\% in Rawal-1 and 70\% in Ajmeri-1. The highest $\mathrm{N}_{2}$ fixation of $68 \mathrm{~kg} \mathrm{ha}^{-1}$ was observed in NARC-2 with foliar application of nutrients. Nodule numbers increased from 0.12 plant $^{-1}$ without nutrients spray to 0.99 plant $^{-1}$ with nutrients spray. Number of pods increased $7.5 \%$ to $45 \%$ with foliar application of nutrients. The highest number of pods (74 per plant) was recorded for Ajmeri-1 with foliar application spray. Increase in biomass yield with foliar application of nutrients was $18 \%$ to $112 \%$. The highest biomass yield was $4.8 \mathrm{t} \mathrm{ha}^{-1}$ from Rawal-1 with nutrients application. Increase in grain yield with foliar application of nutrients ranged between $19.5 \%$ and $132 \%$. The highest seed yield was produced by NARC-2 $\left(2.19 \mathrm{t} \mathrm{ha}^{-1}\right)$ with foliar application of nutrients. The study clearly concludes that foliar application of nutrients significantly increased biological nitrogen fixation, number of pods per plant and finally grain yield in soybean.

Received | January 26, 2018; Accepted | February 26, 2020; Published | October 17, 2020

*Correspondence | Shahzada Sohail Ijaz, Institute of Soil Science, Arid Agriculture University Rawalpindi, Pakistan; Email: shahzadasohail@ uaar.edu.pk

Citation | Awan, M.G.H., S.S. Ijaz, M. Ansar, A. Anwar, U. Abbasi and H. Mahmood. 2020. Influence of foliar application of mineral nutrients on biological nitrogen fixation of rainfed soybean. Pakistan Journal of Agricultural Research, 33(4): 827-833.

DOI | http://dx.doi.org/10.17582/journal.pjar/2020/33.4.827.833

Keywords | Soybean, Foliar application of nutrients, Nitrogen fixation
\end{abstract}

\section{Introduction}

Soybean (Glycine max L.) provides approximately 50\% edible oil of the world (Akparobi, 2009). It has been documented as a former crop plant since the derivation of agriculture (Jandong et al., 2011). Soybean as a food contains significant minerals, such as $\mathrm{Ca}, \mathrm{P}$ and $\mathrm{Fe}$. Due to the huge amount of macro and micro nutrients, soybean has been considered as a nourishing food crop for humans and livestock (Akparobi, 2009; Berglund, 2002).
Foliar application of nutrients is a relatively latest method for crop feeding, in which nutrients in the form of liquid are sprayed onto leaves (Nasiri et al., 2010). It has been reported that foliar application of nutrients is beneficial than soil application (Zayed et al., 2011) especially under rainfed regions where supplemental irrigation is not possible. Foliar application of nutrients is also better option under recently advocated reduced tillage conditions, as the broadcasted fertilizers remain on soil surface. However, there has been renewed interest by growers 
in foliar nutrient applications (Gerwing et al., 2002).

Nitrogen fixation is the natural process of conversion of atmospheric dinitrogen $\left(\mathrm{N}_{2}\right)$ to plant available $\left(\mathrm{NH}_{4}\right)$ form. The biological nitrogen fixation is the symbiotic nitrogen fixation by legumes. It is carried out by the bacteria of genera rhizobium and Bradyrhizobium in association with legume plant roots. The rhizobium enters the plant roots and forms nodules in which they fix nitrogen. Biological nitrogen fixation (BNF) in soybeans is a complex process involving the interplay between the plant host and the symbiotic rhizobia. As accessibility of condensed nitrogen play beneficial role in the enhancement and progress of plants, higher nitrogen fixation capacity is important to achieve better vegetative growth and seed size in soybean (Munoz et al., 2016).

Many research studies have reported that foliar application of mineral nutrients play vital role in the yield (Gowthami and Rao, 2014), oil contents, seed number and seed weight per plant, pod number and quality (Ghasemian et al.,2010; Heidarian et al.,2011). However, studies about the effect of foliar application of mineral nutrients on biological nitrogen fixation of soybean are extremely scarce. Therefore, the main aim of this research was to investigate the effect of foliar application of mineral nutrients on the biological nitrogen fixation of soybean and different agronomic variants of soybean.

\section{Materials and Methods}

A field experiment was performed at University Research Farm in Potohar region, PMAS-Arid Agriculture University Rawalpindi Chakwal Road during summer 2015. The study was aimed to evaluate the biological nitrogen fixation of soybean varieties with and without nutrient application as a foliar spray. The experimental area was located at longitude $73.07^{\circ} \mathrm{E}$, latitude $33.6^{\circ} \mathrm{N}$ and elevation of $517 \mathrm{~m}$ from mean sea level. The climate of Northern Punjab including Potohar region has a considerable temperature variation. Average rainfall range between $750 \mathrm{~mm}$ to $>1000 \mathrm{~mm}$ and temperature ranges from 30 to 45 in summer and 10 to 25 during winter with few exception when temperature goes below zero.

The experiment was laid out in a split plot design with four replications. The main plot treatments were soybean varieties viz. NARC-2, Rawal-1 and
Ajmeri-1. Subplot treatments were foliar nutrient spray i.e. with foliar nutrients and without nutrients spray. Seedbed was prepared once with primary tillage of moldboard plough followed by cross ploughing with cultivator before sowing in August, 2015. Inoculum of Bradyrbizobium was mixed with the seeds before sowing. The innoculum was purchased from NARC that resulted in colony count of $460 \mathrm{CFU} 25 \mathrm{ml}^{-1}$ in soil. The seeds were moistened with small amount of water and sugar. Then inoculum was thoroughly mixed with the seeds in a bag. Seeds were sown on ridges at the rate of $40 \mathrm{~kg}$ per hectare with hands with plant to plant distance of $5 \mathrm{~cm}$ and row to row distance of $65 \mathrm{~cm}$. Fertilizer was applied at the rate of 30-90-50 NPK kg ha ${ }^{-1}$, half of $\mathrm{N}$ and $\mathrm{K}$ was applied at the time of sowing. Diammonium phosphate was used as a source of phosphorus, sulfate of potash was used as a source of potassium, and urea was used as an additional source of nitrogen along with DAP. Earthings were done to remove weeds and support the plant, three times during crop period. Remaining half dose of nitrogen and potash was applied in split application at third trifoliate stage (V3) before last earthing. Foliar micronutrient spray was first applied after one month of germination. Later on foliar sprays were applied at an interval of 15 days (total 4 sprays during the crop period). Micronutrient spray was a commercial formulation that applied $0.7 \mathrm{~g} \mathrm{ha}^{-1} \mathrm{Mn}$, $0.7 \mathrm{~g} \mathrm{ha}^{-1} \mathrm{~B}, 0.7 \mathrm{~g} \mathrm{ha}^{-1} \mathrm{Cu}$, and $1 \mathrm{~g} \mathrm{ha}^{-1} \mathrm{Zn}$ besides 59 $\mathrm{g} h \mathrm{a}^{-1} \mathrm{P}$, and $27 \mathrm{~g} \mathrm{ha}^{-1} \mathrm{Ca}$ in each application.

Soil samples were collected at the time of sowing from 0-20 $\mathrm{cm}$ depth and prepared for determination of soil reaction $(\mathrm{pH})$, electrical conductivity (EC), total organic carbon (TOC), soil texture, nitrate nitrogen, available phosphorus, extractable potassium and micronutrients status (Table 1 ).

\section{Soil analysis}

Soil texture was determined by Bouyoucos Hydrometer method, Total organic carbon was recorded by Walkley and Black (1934) method. Nitrate nitrogen was determined according to the method described by Anderson and Ingram (1993). Available phosphorus was determined by Olsen method (Olsen and Sommers, 1982). Extractable potassium was determined by Flame photometer (Ryan et al., 1996).

\section{Crop parameters}

Number of pods, number of nodules, total biomass 
yield, and grain yield was done by quadrate method. Plant nitrate nitrogen was determined according to the method given by Anderson and Ingram (1993). Biological nitrogen fixation was done by xylem solute technique (Peoples et al., 1989) as given below.

\section{Determination of $\mathrm{N}_{2}$-fixation by xylem solute technique} $\mathrm{N}_{2}$-fixation of soybean was determined by xylem solute method, sap was taken at the pod-filling stage.

Collection of xylem sap: Firstly plant stem was cut near to the level of ground by secateurs. The cutting stem was urgently inserted into the silicon latex rubber tubing sleeve with smaller diameter internally than the stem and then fitted into the needle syringe with appropriate adopter size. Then needle was pushed into the $5 \mathrm{ml}$ of rubber stopper and it was connected to the vacuum pump using another syringe linked of syringe needle and a line of plastic tube. Xylem sap samples were stored into the vaccutainer and adequate volume of ethanol was added to stabilize the sample (Herridge et al., 1988).

Total ureides: Red colour was development by mixing xylem sap with $0.5 \mathrm{~N}$ sodium hydroxide, $0.65 \mathrm{~N} \mathrm{HCl}$ and phenyl hydrazine mixture. Readings were noted after ten minutes at the wavelength of $525 \mathrm{~nm}$ on spectrophotometer (Young and Conway, 1942).

Nitrate-nitrogen: Nitrate Nitrogen determination was done by the salicylic acid method. After colour development, optical density was recorded on the spectrophotometer at the wavelength of $410 \mathrm{~nm}$ (Cataldo et al., 1975).

Total amino-nitrogen: Analysis of total amino nitrogen was determined by ninhydrin method. Color was developed blue and optical density was recorded on the spectrophotometer at the wavelength of 570 nm (Yemm and Cocking, 1955).

Calculation of the Ureides, Nitrate and Amino Nitrogen Concentration.

Sample conc. $=$ Standard conc. ${ }^{*}[$ Optical density of sampleloptical density of standard] $]^{*}$ Dilution $m M$

As to calculate Ureides, nitrate and amino nitrogen, five standards of different concentrations were made but any value of standard was put into the formula.

Calculations of the relative abundance of ureide- $\mathrm{N}$
(\%RUN). It was calculated by using the following formula.

$\% R U N=\left[(4 *\right.$ ureides $) /\left(4 *\right.$ ureide ${ }^{*}$ Nitrate ${ }^{*}$ Amino $\left.)\right] * 100$

Calculation of the $\% \mathrm{P}_{\text {fix }}$

To calculate the plant $\mathrm{N}$ derived from the nitrogen fixation $\left(\% \mathrm{P}_{\text {fix }}\right)$ following formula was used:

$\% P_{f x x}=1.6(\% R U N-13.5)$ for plants during pod fill stage

Calculation of total Nitrogen fixed $\left(\mathrm{kg} \mathrm{ha}^{-1}\right)$

The legume $\mathrm{N}$ was calculated by using the following formula.

Legume $N\left(\mathrm{~kg} \mathrm{ha}^{-1}\right)=$ Legume dry matter $\left(\mathrm{kg} \mathrm{ha}^{-1}\right)^{*}(\% \mathrm{~N})$

The amount of nitrogen fixed by legume is regulated by two factors. The amount of $\mathrm{N}$ accumulated during growth and the production of that nitrogen derived from symbiotic nitrogen fixation $\left(\% \mathrm{P}_{\text {fix }}\right)$ Amount of Nitrogen fixed $\left(\mathrm{kg} \mathrm{ha}^{-1}\right)=\% P_{f x}$. Legume N
\[ \left(\mathrm{kg} \mathrm{ha}^{-1}\right)^{*} 1.5 \]

* 1.5 factor is used to include contribution by below ground N (Peoples et al., 1989).

Table 1: Physiochemical properties of experimental soil.

\begin{tabular}{|c|c|c|}
\hline Soil property & Unit & Mean value \\
\hline Soil texture & & Sandy loam \\
\hline Soil pH & & 7.7 \\
\hline $\mathrm{ECe}$ & $\mathrm{dSm}^{-1}$ & 0.23 \\
\hline Soil organic C & $\%$ & 0.93 \\
\hline Nitrate N & $\mathrm{mg} \mathrm{kg}^{-1}$ & 3.8 \\
\hline Available P & $\mathrm{mg} \mathrm{kg}^{-1}$ & 6 \\
\hline Extractable K & $\mathrm{mg} \mathrm{kg}^{-1}$ & 117 \\
\hline Boron & $\mathrm{mg} \mathrm{kg}^{-1}$ & 0.43 \\
\hline Manganese & $\mathrm{mg} \mathrm{kg}^{-1}$ & 0.32 \\
\hline Iron & $\mathrm{mg} \mathrm{kg}^{-1}$ & 1.76 \\
\hline Copper & $\mathrm{mg} \mathrm{kg}^{-1}$ & 0.32 \\
\hline Zinc & $\mathrm{mg} \mathrm{kg}^{-1}$ & 0.74 \\
\hline Soil Classification & & Rajar series,' \\
\hline
\end{tabular}

Rainfall and maximum and minimum temperature data was taken from the automatic weather station installed at University Research Farm, Chakwal Road of PMAS-Arid Agriculture University Rawalpindi 
(Figure 1). The data collected for soil and plant variables was analyzed by ANOVA and treatment means obtained was compared by LSD at $5 \%$ level of significance (Steel et al., 1997).

\section{Results and Discussion}

\section{Number of pods}

Data given in Table 2 showed that average number of pods in soybean varieties NARC-2, Rawal-1 and Ajmeri-1 were 55.6, 40.2, and 52.0 plant $^{-1}$ without nutrients spray, and 69.6, 43.7 and 74.7 plant $^{-1}$ with nutrient spray respectively and thus the increase in number of pods with foliar application of nutrients was $25 \%, 7.5 \%$ and $45 \%$. Foliar nutrients significantly increased number of pods in NARC-2 and Ajmeri-1 varieties but Rawal-1 did not show statistically appreciable increase in pods.

Table 2: Crop parameters as affected by foliar nutrients application.

$\begin{array}{llllll}\text { Variety } & \begin{array}{l}\text { Nu- } \\ \text { trients } \\ \text { spray }\end{array} & \begin{array}{l}\text { Number } \\ \text { of pods }^{\left(\text {plant }^{-1}\right)}\end{array} & \begin{array}{l}\text { Nodules } \\ \text { count } \\ \left(\text { plant }^{-1}\right)\end{array} & \begin{array}{l}\text { Biomass } \\ \text { yield } \\ \left.\text { (t ha }^{-1}\right)\end{array} & \begin{array}{l}\text { Grain } \\ \text { yield } \\ \text { (t ha }^{-1} \text { ) }\end{array} \\ \text { NARC-2 } & \text { without } & 55.9 \mathrm{~b} & 0.39 \mathrm{bc} & 3.4 \mathrm{c} & 1.47 \mathrm{c} \\ & \text { with } & 66.7 \mathrm{a} & 0.99 \mathrm{a} & 4.1 \mathrm{ab} & 2.19 \mathrm{a} \\ \text { Rawal-1 } & \text { without } & 40.2 \mathrm{~b} & 0.12 \mathrm{c} & 4.05 \mathrm{bc} & 1.23 \mathrm{de} \\ & \text { with } & 43.7 \mathrm{~b} & 0.38 \mathrm{bc} & 4.8 \mathrm{a} & 1.47 \mathrm{c} \\ \text { Ajmeri-1 } & \text { without } & 52.0 \mathrm{~b} & 0.19 \mathrm{c} & 1.6 \mathrm{~d} & 1.22 \mathrm{e} \\ & \text { with } & 74.7 \mathrm{a} & 0.69 \mathrm{ab} & 3.4 \mathrm{bc} & 1.84 \mathrm{~b}\end{array}$

Pods increased results in NARC-2 and Ajmeri-1 varieties with foliar nutrients were in line with Ghasemian et al. (2010) and Bellaloui et al. (2010) who reported increase in number of pods in soybean with the application of foliar nutrients.

Interestingly, Rawal-1 did not show any positive response to nutrients spray on number of pods, indicating that nutrients spay might not increase grain yield in this variety. The Rawal- 1 variety is basically focused on biomass production for fodder purposes. Therefore, its number of pods is relatively lesser than other varieties.

\section{Number of nodules}

The data pertaining to nodule count per plant given in Table 2 showed that nodule numbers of variety NARC-2, Rawal-1 and Ajmeri-1 was 0.39, 0.12, and 0.19 plant $^{-1}$ from plots without nutrients application, and $0.99,0.38$ and 0.69 plant $^{-1}$ with nutrients spray.
At site most of the plants had no nodules and only one out of three plants on average had one nodule. Foliar application of nutrients significantly improved nodule count. The highest nodule count was obtained from NARC-2 with foliar nutrients spray. The lowest nodule count was observed in Rawal-1 without nutrients spray.

Overall the entire nodule formation was very poor because it was first year of soybean cultivation in the experimental field. Nodule formation in legumes is carried out by Rhizobium bacteria, which are specific to host crops. There are six cross-inoculation groups of Rhizobium that can symbiotically fix nitrogen in their specific host group. In soybean Rhizobium japonicum is the specific bacteria that can initiate nodule formation. The population of these bacteria increases gradually with the repeated cultivation of soybean. It is, therefore, expected that if soybean is grown for successive 3 to 4 years, then there is possibility of more nodule formation.

The nutrients spray increased nodulation in all varieties especially in NARC-2. These observations have also been reported by other researchers such as Zahoor et al. (2013) under similar conditions that nodulation increased in soybean with the application of foliar nutrients. The Mo and Fe are components of specific plant enzyme called nitrogenase which is involved in key step of reduction of nitrogen to ammonia in the process of nitrogen fixation (Hegazi et al., 2011). Application of Fe not only enhances activity of nitrogenase enzyme but also serve as an important element for rhizobia nutrition (Hara, 2001).

\section{Biomass yield}

Data pertaining to biomass yield given in Table 2 showed that nutrients application significantly improved biomass yield. The data showed that biomass yield of variety NARC-2, Rawal-1 and Ajmeri-1 varieties was $3.4,4.05$, and $1.6 \mathrm{t} \mathrm{ha}^{-1}$ without nutrients spray, and 4.1, 4.8 and $3.4 \mathrm{tha}^{-1}$ with nutrients spray. The increase in biomass ranged from $12 \%$ in Ajmeri-1 to $20 \%$ in NARC-2. Rawal-1 variety produced the highest biomass yield. The lowest biomass yield was observed in NARC-2 without nutrients spray.

Many other researchers such as Heidarian et al. (2011) and Gascho (1993) reported improved biomass yield with nutrients spray. Overall Rawal-1 represented the highest biomass yield indicating the forage potential in the ecological regions of Pothwar. 
The lower biomass with nutrients spray could be due to the fact that site has lower rainfall and being a biomass oriented variety Rawal- 1 could have experienced some water stress than other varieties. Spray of nutrients during stress could have caused suppression of growth.

\section{Grain yield}

Data regarding grain yield presented in Table 2 showed that grain yield of variety NARC-2, Rawal-1 and Ajmeri-1 produced 1.47, 1.23 and 1.22 t grain seeds $\mathrm{ha}^{-1}$ without nutrients spray, and $2.19,1.47$ and $1.84 \mathrm{t} \mathrm{ha}^{-1}$ respectively with nutrients spray and the increase in grain yield with foliar application of nutrients was $48 \%, 19.5 \%$ and $132 \%$. Nutrients spray significantly improved the seed yield. Nutrients spray significantly improved the seed yield. The highest seed yield was produced by soybean variety NARC-2 with foliar nutrients spray, while the lowest seed yield was recorded in Rawal- 1 without nutrients spray with intermediate seed yield by Ajmeri- 1 with nutrients spray.

The increase in grain yield with nutrients spay was about 50\% in NARC-2 and Ajmeri-1 varieties. The same varieties had higher number of pods given in Table 2 . The considerable increase in grain yield with nutrients foliar application has repeatedly been report by many researcher such as Zahoor et al. (2013), Odeleye et al. (2007), Kobraee et al. (2014), (Ghasemian et al., 2010) and Heidarian (2011).

\section{Nitrogen fixation}

Data pertaining to total nitrogen fixed is presented in Figure 2 showed that total nitrogen fixed under NARC-2, Rawal-1 and Ajmeri-1 varieties was 34,31, and $23 \mathrm{~kg} \mathrm{ha}^{-1}$ without nutrients spray, and 68,57 and $39 \mathrm{~kg} \mathrm{ha} \mathrm{h}^{-1}$ with nutrients spray and the increase in biological nitrogen fixation was $100 \%, 84 \%$ and 70 $\%$ respectively. Nutrients spray significantly improved the total nitrogen fixation. The highest total nitrogen fixed by variety NARC- 2 with foliar nutrients spray. The lowest total nitrogen fixed was recorded in NARC-2 without nutrients spray closely followed by Ajmeri-1 with nutrients spray.

It is evident from the results that foliar application of nutrients ( $\mathrm{Fe}, \mathrm{Zn}, \mathrm{Mn}, \mathrm{Cu}, \mathrm{P}$ and $\mathrm{Ca}$ ) considerably increased the biological nitrogen fixation in soybean. The increase ranged from $70 \%$ in Ajmeri-1 to $100 \%$ in NARC-2. Thus nutrients spray almost doubled the nitrogen fixation of soybean. This information is very valuable because previously such studies have rarely been reported especially in soybean crop. Most of the previous studies report increase in nodule count (Zahoor et al., 2013), yield (Gowthami and Rao, 2014), oil contents (Ghasemian et al., 2010), seed number and seed weight per plant (Heidarian et al., 2011), pod number and quality of soybean (Latif and Haggon, 2011; Vahedi, 2011).

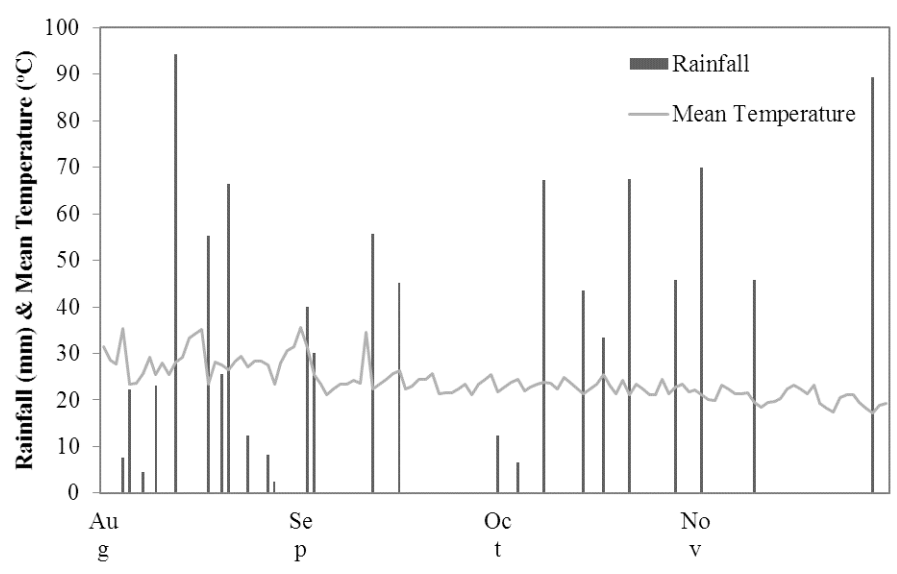

Figure 1: Daily rainfall $(\mathrm{mm})$ and daily mean temperature $\left({ }^{\circ} \mathrm{C}\right)$ during the growth period of soybean (August-Nor, 2015).

The highest nitrogen fixation observed in NARC-2 variety is also verified with the data on nodule number (Figure 2) that shows that number of nodules of NARC-2 were greater as compared to Rawal- 1 and Ajmeri-1. The nodule numbers are beneficial when used together with field measurement of $\mathrm{N}_{2}$ fixation and can help in the understanding of data obtained (Peoples et al., 1989).
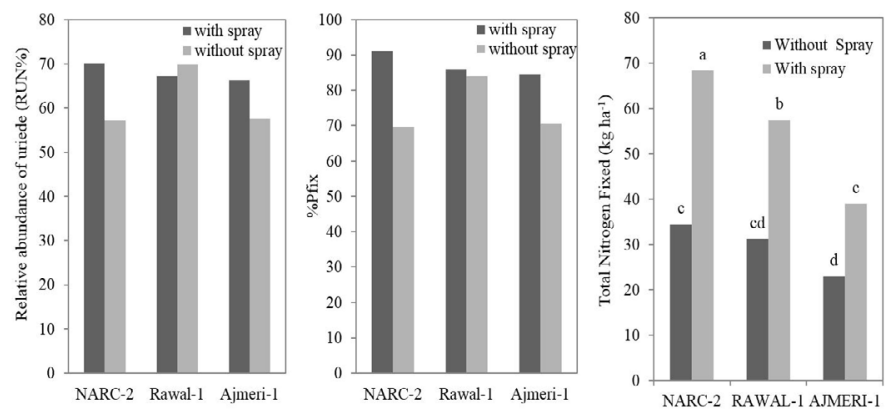

Figure 2: \%RUN, \%Pfix and total nitrogen fixed of different soybean varieties as affected by foliar nutrients application.

\section{Conclusions and Recommendations}

Foliar application of nutrients considerably enhanced biological nitrogen fixation of all the tested soybean varieties. As regards grain yield, NARC-2 and Ajmeri-1 varieties which are seed purpose varieties showed positive response while Rawal- 1 which is a fodder/forage purpose variety did not respond 
positively to foliar application of nutrients. The field research investigations clearly showed that the soybean crop can be successfully grown in the Pothwar region and foliar application of nutrients should be recommended to the farmers.

\section{Novelty Statement}

Improvement in yield of soybean varieties grown in Pakistan with the foliar application of nutrients has been reported but associated change in $\mathrm{N} 2$ fixation has not been quantified. Therefore current study provides quantitative change in $\mathrm{N} 2$ fixation in response to foliar applied nutrients.

\section{Author's Contribution}

Malik Gul Hassan Awan conducted field experiment and collected data. Shahzada Sohail Ijaz conceived the idea and supervised the experiment. Muhammad Ansar provided technical input at every step of crop. Adeel Anwar helped in field operations. Umber Abbasi conducted statistical analysis. Hashmat Mahmood helped in laboratory analysis. Muhammad Sarwar gave input in the writeup and review of article.

\section{Conflict of interest}

The authors have declared no conflict of interest.

\section{References}

Akparobi, S.O., 2009. Evaluation of six cultivars of soybean under the soil of rainforest agroecological zones of Nigeria. Middle-East J. Sci. Res. 4: 06-09.

Anderson, J.M. and J.S.I. Ingram. 1993. Tropical soil biology and fertility. A handbook of methods. CAB International, Wallingford, U. K. pp. 70-87.

Bellaloui, N., K.N. Reddy, A.M. Gillenand and C.A. Abel. 2010. Nitrogen metabolism and seed composition as influenced by foliar boron application in soybean. Plant Soil. 336: 143155. https://doi.org/10.1007/s11104-0100455-6

Berglund, D.R., 2002. Soybean production field guide for North Dakota and Northwestern Minnesota. Published in cooperative and with support from the North Dakota Soybean Council, pp. 136.

Cataldo, D.A., M. Haroon, L.E. Sharader and V.L.
Youngs. 1975. Rapid colorimetric determination of nitrate in plant tissue by nitration of salicylic acid. Commun. Soil Sci. Plant Anal., 6: 71-80. https://doi.org/10.1080/00103627509366547

Gascho, G.J., 1993. Boron and nitrogen applications to soybeans: foliar and through sprinkler irrigation. In Foliar Fertilization of Soybeans and Cotton, PPI/FAR Tech. Bull. Soil Sci. Soc. Am. Proc. pp. 1993-1.

Gerwing, J.A.B., R. Gelderman and R. Berg. 2002. Foliar nutrient application influence on soybean yield at Aurora and Berestord SD in 2003. Agricultural experiment station plant science department. South Dakota State Univ. Plant Sci. 315: 65-69.

Ghasemain, V., A Ghalavanda, A.S. Zadeh and A. Pirzad. 2010. The effect of Iron, zinc and manganese on quality of soybean seed. J. Phytol. 2: 73-79.

Gowthami, P. and R.G. Rama. 2014. Effect of foliar application potassium, boron and zinc on growth analysis and seed yield in soybean. Int. J. Food, Agric. Vet. Sci., 4: 73-80.

Hara, G.W., 2001. Nutritional constrains on root nodule bacteria affecting symbiotic nitrogen fixation: a review. Australian. J. Exp. Agric. 41: 417- 433. https://doi.org/10.1071/EA00087

Hegazi, A., M.A. Mohamed, A.G.S. Sayed, M.H. Elsherif and N. Gad. 2011. Reducing N doses by enhancing nodule formation in groundnut plants via Co and Mo. Australian. J. Basic Appl. Sci. 5: 2568-2577.

Herridge, D.F., P.O. Connell, and K. Donnelly. 1988. The xylem uried assay of nitrogen fixation: Sampling procedure and sources of error. J. Exp. Bot., 39: 12-22. https://doi.org/10.1093/ jxb/39.1.12

Heidarian, A.R., H. Kord, K. Mostafaviz, A.P. Lak and F.A. Mashhadi. 2011. Investigating $\mathrm{Fe}$ and $\mathrm{Zn}$ foliar application on yield and its components of soybean (Glycine max (L) Merr). At different growth stages. J. Agric. Biotechnol. Sustainable Dev., 3: 189-197.

Jandong, E.A., M.I. Uguru and B.C. Oyiga. 2011. Determination of yield stability of some soybean genotypes (Glycine $\max$ (L.) merr) across diverse soil $\mathrm{pH}$ levels using GGE biplot analysis. J. Appl. Biosci. 43: 2924-2941

Kobraee, S., K. Shamsi and M.S. Vaghar. 2014. Effect of irrigation and micronutrient foliar application on quality and quantity parameters 
of soybean. Curr. Biotica. 8: 13-20.

Latif, E.M and M.A.E. Haggon. 2011. The effect of micronutrients foliar application on yield and quality traits of soybean cultivars. Int. J. Agric. Crop Sci. 7: 908-914.

Munoz, N., X. Qi, M.W. Li, M. Xie, Y. Gao, M.Y. Cheung, F.L. Wong and H.M. Lam. 2016. Improvement in nitrogen fixation could be part of domestication process in soybean. Heredity, 117: 84-93. https://doi.org/10.1038/ hdy.2016.27

Nasiri, Y., S. Zehtab-Salmasi, S. Nasrullahzadeh, N. Najafi and K. Ghassemi- Golezani. 2010. Effects of foliar application of micronutrients ( $\mathrm{Fe}$ and $\mathrm{Zn}$ ) on flower yield and essential oil of chamomile (Matricaria chamomilla L.). J. Med. Plants Res. 4: 1733-1737.

Odeleye, F.O., O.M. Odeleye and M.O. Animashaun. 2007. Effect of nutrients foliar spray on soybean growth and yield (Glycine max (L.) Merrill) in the south west Nigeria. Not. Bot. Hort. Agrobot. Cluj. 35: 22-32.

Olsen, S.R. and L.E. Sommers. 1982. Phosphorus. In: Page, A.L., R.H. Miller and D.R. Keey. Eds. Methods of soil analysis Part 2. Amer. Soc. Agron. No.9. Madison, Wisconsin, USA. pp. 403-427.

Peoples, M.B., A.W. Faizah, B. Rekasem and D.F. Herridge. 1989. Methods for evaluate nitrogen fixation by nodulated legumes in the field. ACIAR Monograph. 11: 22-45.

Ryan, J., G. Estefan and A. Rashid. 2001. Soil and plant analysis laboratory manual. ICARDA, Aleppo, Syria.
Ryan, J., K. Harmsen and A. Rashid. 1996. A Soil and Plant Analysis Manual. Adopted for the West North Africa Region. ICARDA, Aleppo, Syria.pp. 140.

Steel, R.G.D., J.H. Torrie and D.A. Dicky. 1997. Principles and procedures of Statistics. A biometrical Approch: $3^{\text {rd }}$ Ed. McGraw Hill Book Co. Inc. New York. pp. 400-428.

Vahedi, A., 2011. The effect of micronutrient application on soybean seed yield and on seed oil and protian content. J. Am. Sci., 7 (6): 672677.

Walkely, A. and C.A. Black. 1934. A critical examination of a rapid method for determination of organic carbon in soils: Effect of variations in digestion conditions and of organic soil constituents. Soil Sci. pp. 251-263.

Young, E.G. and C.F. Conway. 1942. On the estimation of allantoin by the riminischryver reaction Analysis. J. Biol. Chem. 142: 839-853.

Yemm, E.W. and E.F. Cocking. 1955. The determination of amino acids with ninhydrin Analysis. 80: 209-213. https://doi.org/10.1039/ an9558000209

Zahoor, F., M. Ahmed, M.A. Malik, K. Mnbeen, M.H. Siddiqui, M. Rashed, R. Ansar and K. Mehmood. 2013. Soybean (Glycine max L.) response to micronutrients. Turk. J. Field Crops, 18: $134-138$.

Zayed,B.A.,A.K.M.Salem and H.M.El-Sharkawy. 2011. Effect of different micronutrient treatments on rice (Oryza sativa L.) growth and yield under saline soil conditions. World J. Agric. Sci. 7: 179-184. 